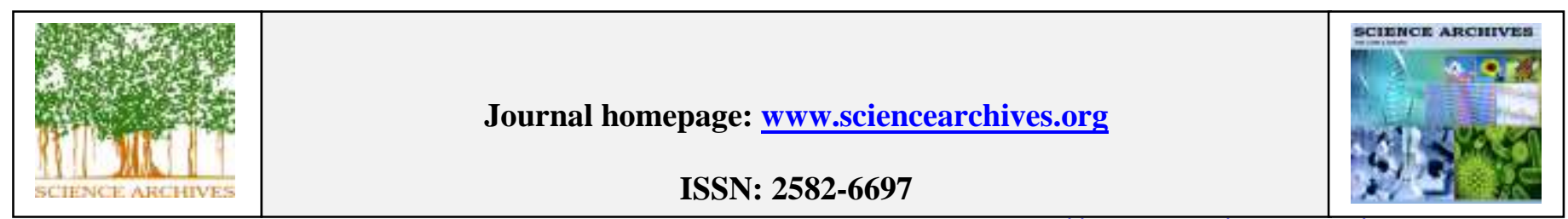

Research Article

http://dx.doi.org/10.47587/SA.2020.1101

\title{
Impact of COVID-19 lockdown on water quality of Dubai creek lagoon
}

\author{
Rajshree $^{1,2}$, Abhishek Chauhan ${ }^{3}$, Anuj Ranjan, ${ }^{3}$, Tanu Jindal ${ }^{1,3}$ \\ ${ }^{1}$ Amity Institute of Environmental Sciences, Amity University, Sector-125, \\ Noida, Uttar Pradesh, India \\ ${ }^{2}$ Tridel Technologies, FZC, QDO1, Dafza Industrial park, Al Qusais, Dubai, UAE. \\ ${ }^{3}$ Amity Institute of Environmental Toxicology, Safety and Management, Amity University, Sector-125, \\ Noida, Uttar Pradesh, India \\ [x.akchauhan@amity.edu; mail4mons@gmail.com \\ Received Date: April 12, 2020 / Accepted Date: June 19, 2020 / Published Date: June 25, 2020
}

\begin{abstract}
Dubai creek lies at the heart of Dubai. It has aesthetic value as it provides $14 \mathrm{~km}$ waterfront and attractive living space for residents and tourists. The creek breezes It's way with the opening, which is a hundred meters wide, into the Arabian Gulf and extends $7 \mathrm{~km}$ inwards into a wide lagoon with twelve-hundred-meter opening. Till 2016 the creek was an enclosed water body. Poor flushing of the water in the creek made pollutants to reside in the creek water for a longer time. In November 2016, Roads and Transport Authority (RTA) inaugurated the Dubai Canal, which is an extension of Dubai Creek, making a complete Ushaped open waterbody. Dubai creek is highly impacted by residential sprawl in recent year. One of the major sources of wastewater input into the creek and contaminating it is the effluents from Al Aweer sewerage treatment plant (STP). Many studies done on Dubai creek previously showed that the water quality was not up to the mark to support good living environment especially for migratory birds in the Ras Al Khor Sanctuary which is rich in more than 250 species of migratory birds and mangroves. The aim of this study is to determine the quality of creek water before, during and after the lockdown amidst the Covid-19 Pandemic. Lockdown was from 6th - 23rd April 2020 in U.A.E. The data is being collected from official Dubai coastal monitoring site of Dubai Municipality 'www.dubaicoast.ae' through real-time water quality monitoring sensors which are being deployed in water buoys in Dubai creek lagoon by Dubai Municipality. The results showed improvements in the water quality of the lagoon during the lockdown. The overall quality of the water improved because of less industrial operating hours during the lockdown. The opening of the canal might have minor positive effects on lagoon water due to better circulation. There was significant improvement noted in the DO, Turbidity, Salinity, Chlorophyll (a), pH and BGA during the Lockdown. However, no significant effects were observed in the water temperature of the Lagoon.
\end{abstract}

Keywords: Dubai creek, Water Quality, Treatment Plant, COVID-19, Lockdown

\section{Introduction}

Dubai is one of the seven emirates of United Arab Emirates (U.A.E) rest six includes Abu Dhabi, Sharjah, Ras Al Khaimah, Ajman, Umm Al-Qaiwain and Fujairah. Dubai has a nearly 70-kilometre long coastline along the Arabian Gulf shore. UAE is particularized by high dissipation rate, scanty rainfall and high mercury level (Murad, 2010). There is very scarce groundwater available in the UAE therefore, desalinated seawater from the Arabian Gulf is utilized for local and modern purposes (Freije, 2015). Dubai creek is a 7 $\mathrm{km}$ long water trench which divides Dubai into two parts, Deira and Bur Dubai. It has it's opening in Arabian gulf and ends in a wide lagoon which hosts its way to Ras al Khor wildlife sanctuary. It is a natural inlet and maintains the same water quality and salinity as the Arabian gulf ( $\sim 38-42 \mathrm{ppt})$. In November 2016, the Dubai creek was extended into an artificial man-made Dubai canal. It is $3.2 \mathrm{~km}$ long, extending 
from Dubai Creek lagoon and opens up into the Arabian Gulf, passing from Business Bay. There is a water quality monitoring station in the lagoon which plays a key role in monitoring and analysis of the Dubai Creek lagoon and its water quality parameters. Monitoring water quality in this century is a great challenge, with growing urbanization and industrialization where everything manufactured once, makes its way to the water. The sprawling trade and commerce in such an economically focal point of the world, Dubai needs to be technically equipped with advanced environmental monitoring systems. Dubai Creek is surrounded by luxurious hotels, remarkable architecture, attractive residential buildings and world-class entertainment. It hosts the way for water trading, dhow cruise restaurants, and sporting events as well. This makes the water monitoring extremely essential to keep a track on water parameters to keep the ongoing activities safe and sound. Real-time water monitoring systems are increasingly used in the decision-making process to provide up-to-date information in various fields of science especially environmental monitoring like flood forecasting, tide level monitoring, water supply management, irrigation, and hydro generation. Hydrometric perceptions combined with constant monitoring give the basis for target analysis of water assets, permitting operators to think about various working criteria and the effect of any choice, quickly, proficiently and reliably.

Lately, UAE had an expansion in its populace because of huge urbanization. Dubai Creek is a saltwater body in Dubai which has been affected by the urbanization. The anthropogenic exercises including removal of treated sewage wastewater, effluents from desalination plants and industrial effluents and waste from ships transporting goods or tourism industry can have a critical effect on the water quality of the creek. The water quality corruption in Dubai Creek is a genuine concern which should be researched to safeguard the water life and to keep the tourism industry engaged as it is in Dubai. There is no much work done on the water quality of the creek before however, we assume that the construction of the Dubai canal must have led to improving the water quality. The Covid-19 Lockdown have also proven to improve the water quality in many parts of the world as humans reside inside and industries are closed, it is acting as a ventilator for water bodies to breathe again with good dissolved oxygen. The aim of current study was to monitor the water quality before, during and after Covid-19 Lockdown using water quality monitoring sensors.

\section{Hydrology of Creek}

The Dubai Creek is a major attraction in Dubai, and it provides Dubai with main important services. The creek is not a simple water system. Its velocity is varying and hence makes it a complex system and it is hence very much affected by I's hydrology. The creek is divided into two parts, wide Upper creek (UC) and Narrow Lower creek
(LC) (Deshgooni, 2000). The velocity is high at LC and lowers at UC as LC has narrow opening hence velocity increases and $\mathrm{UC}$ has a wider opening and lower velocity (Al Zahed, 2008).

\section{Sources of input in the creek}

The Creek has 34 known input sources and potential sources of pollution including:

a) Agricultural runoff

b) Oil spills that result from ship leakage, oil production, exploration, and transportation.

c) Desalination plants that on daily basis discharges rejected water

d) Untreated sewage from conventional ships called dhows situated in the lower stream

e) And the largest single source of organic pollution is effluents from Al Aweer Sewerage.

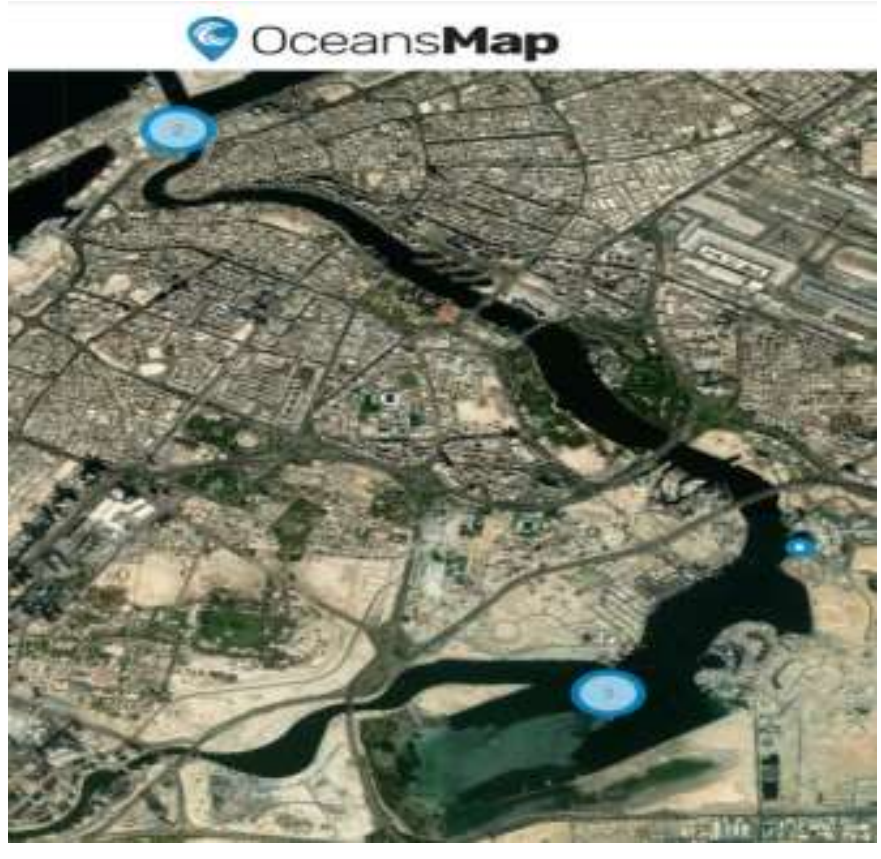

Fig.1 Map of Dubai creek with station installed in Lagoon Source: www.dubaicoast.ae

\section{Treatment Plant (STP)}

The municipality sewage collected from all over the Dubai city is secondary level treated in Al Aweer STP plant and discharged into the creek water. Effluent discharge from STP is the primary cause of nutrient in the lagoon. The dewatering pump stations release nearly five thousand liters of water per day into the creek. The water is rich in 
Nitrogen, minerals and suspended particles. Activities like shipping of cargos, import and export take place in the creek and hence waste from dhow cruises like human sewerage waste, oil leaks and other garbage make its way to the creek water. Dubai ship repairing yard in Al Jaddaf releases a large number of effluents containing metals and petroleum products (Al Zahed, 2008). Additionally, the nitrogen waste from bird faeces (guano) into the creek promotes nutrient level in the creek (Al Zahed, 2008).

More than $100000 \mathrm{~m} 3 /$ day of secondary treated water is discharged into the lagoon from Al Aweer sewage treatment plant. Municipal water from all over the city comes to Al Aweer STP and is being treated here.

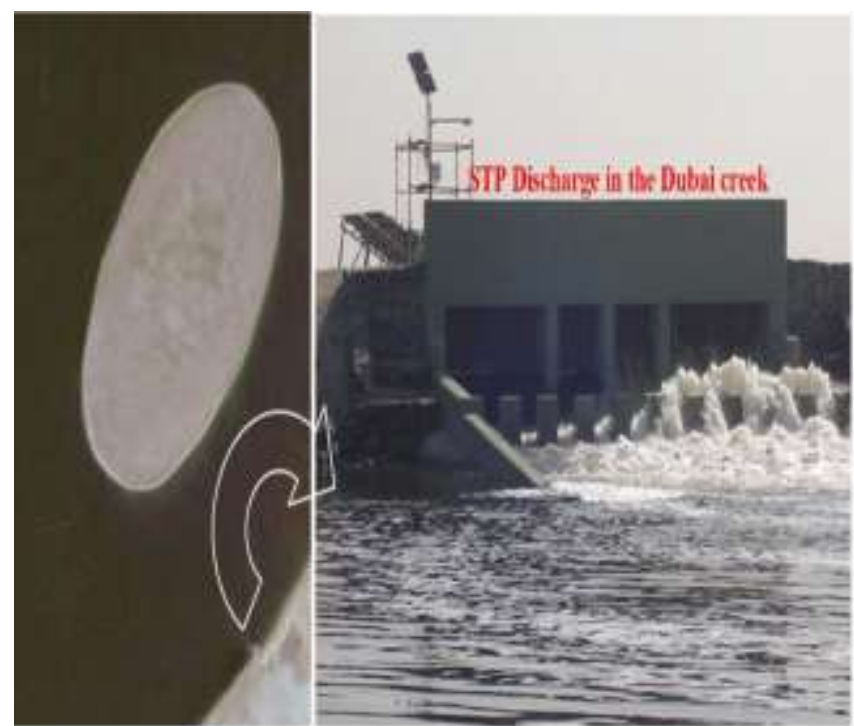

Fig 2: Showing Al Aweer STP discharge in the Lagoon

\section{Impact of Covid-19 lockdown on waterbodies}

Amidst the busy and economically productive lifestyle of humans, sudden nationwide lockdown due to novel coronavirus pandemic (COVID-19) brought human life to halt. The new decade didn't start on a good note for humans, but it is proving to be a ventilator for our environment and natural resources. It happened in the first time of modern human history that everything suddenly stopped, from industries to vehicular movements, humans are locked in their own houses, letting nature breath and recharge.

For quite a while, it has been expressed in different writing that the expanded industrialization and anthropogenic exercises over the most recent two decades severely contaminated the air, water and land. Individuals' developments and modern exercises are shut down for more than a month now, pollutant discharges like the industrial effluents containing heavy metals, petroleum hydrocarbons, oil spillage from shipping and cruise tourism have been partially or completely halted during the Lockdown period in more than 210 countries worldwide which are hit by the Novel coronavirus pandemic. In this manner, the level of contamination is relied upon to be reduced and it is likely to make some positive effects on the existing problems in the environment. Taking Grand canal of Italy as an example, recently due to complete lockdown, as the nation was crippled due to COVID-19, the water of the canal turned clear and the return of many dolphins, swans and fishes have been reported (Clifford, 2020). Likewise, the Ganges, a holy river in India that originates from Gangotri in the Himalayas stretching up to 2,601 km ending in the Bay of Bengal, got cleaner in many places due to lockdown which started on 21st March 2020 (Mani, 2020). Not even Namami Gange could do what lockdown did. Vembanad lake is the longest lake in India, it was found that the lake was severely polluted with plastics, diesel used in houseboats or boats used for tourism of the lake and toxic heavy metal in the sediment of the lake like mercury (Mohan et al., 2014; Ramasamy et al., 2017). As the nation went under lockdown, the industrial pollution activities around the lake halted, however, some domestic activities did not cease completely (Yunus et al, 2020). The effluents from industries and travel industry severely affected the lake water quality. The suspended particulate matter during the lockdown decreased by $15.9 \%$ than those in the prelockdown period in the lake (Yunus et al, 2020). In a study done on river Ganga along with the city of Kolkata, total of 6 sites were tested for Dissolved Oxygen quality. The DO compared to previous years data increased by 33.97 to $35.71 \%$ on all the six locations (Mitra and Mitra, 2020).

Table 1: Showing Station name, number and their coordinates

\begin{tabular}{|c|c|}
\hline Station No. and Name & Station Coordinates \\
\hline $\begin{array}{c}\text { Business Bay Station } \\
\text { (Sonde 1) }\end{array}$ & $25^{\circ} 12.0332^{\prime}$ N $55^{\circ} 19.9173^{\prime}$ \\
& $\mathrm{E}$ \\
\hline Business Bay Station & $25^{\circ} 12.1031^{\prime} \mathrm{N}$ \\
(ADCP) & $55^{\circ} 19.96107^{\prime} \mathrm{E}$ \\
& \\
\hline
\end{tabular}

\section{Methodology}

The data were collected using real-time water quality monitoring sensors which are installed in water buoys by Dubai Municipality. The real-time data was continuously updated for visualization on the website and was being collected from the server. The reading was taken three times a day with four hours gap, the first reading at 9 am second reading at $1 \mathrm{pm}$ and third reading at $5 \mathrm{pm}$. The data were recorded in an Excel sheet, 
processed and results are explained with the help of graphs. The Creek Lagoon station was selected as it has a history of eutrophication as well as it is an important ecological site due to Ras Al Khor wildlife sanctuary. Since the project of Dubai creek Harbour or the Dubai Creek Tower is under construction, it is going to be the tallest tower in the world and major tourism attraction. The creek harbour will be directly facing the lagoon and hence this made it important to monitor the Lagoon water quality. The water buoys are equipped with Sonde Water quality probe which has sensors for monitoring Depth, Water Temperature, Salinity, Dissolved Oxygen, Turbidity, $\mathrm{pH}$, Chlorophyll (a) and BGA cell count. All the buoys are equipped with Solar cells and operate on green energy.

\section{Results and Discussion}

The results show that water temperature changes with air temperature. The minimum and maximum water temperature recorded in this study was $25.34{ }^{\circ} \mathrm{C}$ and 30.09 ${ }^{\circ} \mathrm{C}$. The mean water and air temperature recorded was 27.7 ${ }^{\circ} \mathrm{C}$ and $33.8{ }^{\circ} \mathrm{C}$, respectively. The temperature of Dubai lagoon is slightly higher than the creek water (Al Zahed, 2008; Al Tunaiji, 2016) and this statement has been supported by various studies done before. This is because of effluent discharge from STP. The drop water temperature on 15 th $\& 16$ th April might be due to freshwater input due to rain. U.A.E. was under lockdown during COVID-19 Pandemic from 6th to 23rd April 2020. The water transport, private ships, cruise tourism etc was abandoned during this time. The industries were being operated with $30 \%$ staff with limit hours $(\sim 6)$ of opening per day. The results show there was not much significant effect of lockdown on the water temperature of the creek.

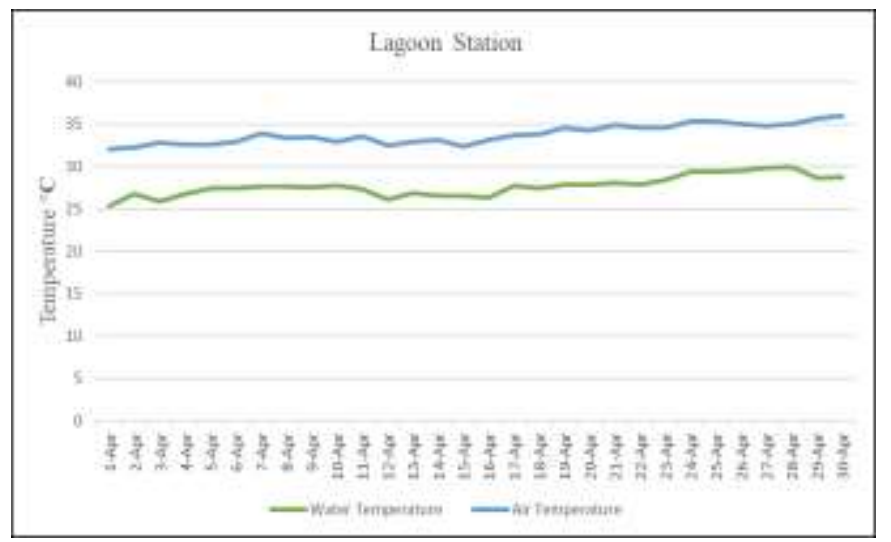

Fig. 3: Shows Pre-Lockdown, Lockdown (6-23rd April) \& Post Lockdown data of Dubai Creek Lagoon Water and Air Temperature of Dubai.

The salinity is in the range of $35.97-39.43 \%$. The mean salinity level was $38.08 \%$. The salinity level of the Dubai creek lagoon is comparatively lower than the creek water (Al Zahed, 2008; Al Tunaiji, 2016) and this statement has been supported by various studies done before. This is because there is a large amount of freshwater input into the creek from AL Aweer STP plant and pumped groundwater discharge and stormwater from construction sites.

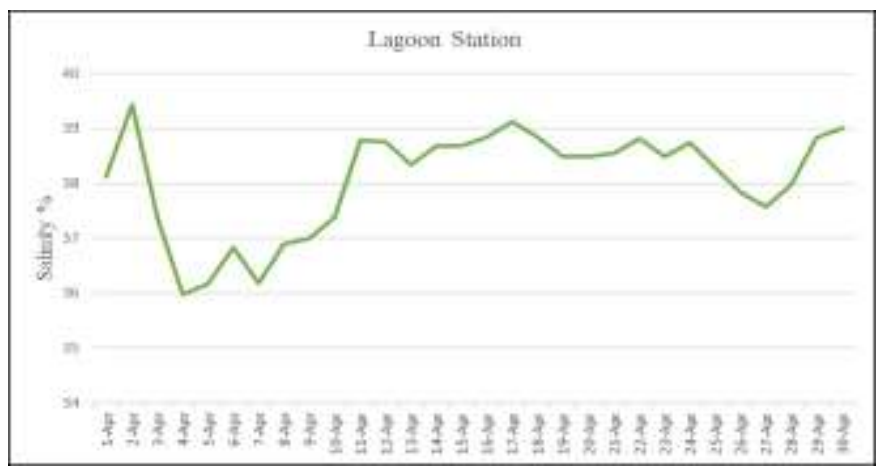

Fig. 4: Shows Pre-Lockdown, Lockdown (6-23rd April) \& Post Lockdown data of Salinity of Dubai Creek Lagoon

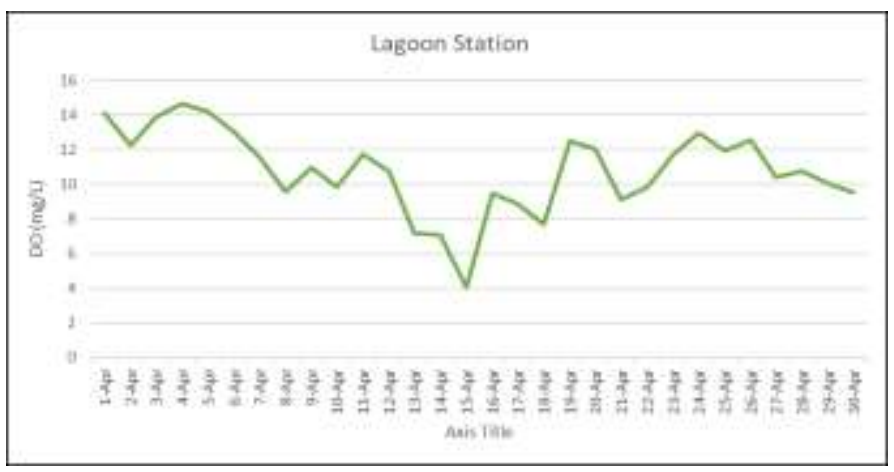

Fig. 5: Shows Pre-Lockdown, Lockdown (6-23rd April) \& Post Lockdown data of DO of Dubai Creek Lagoon

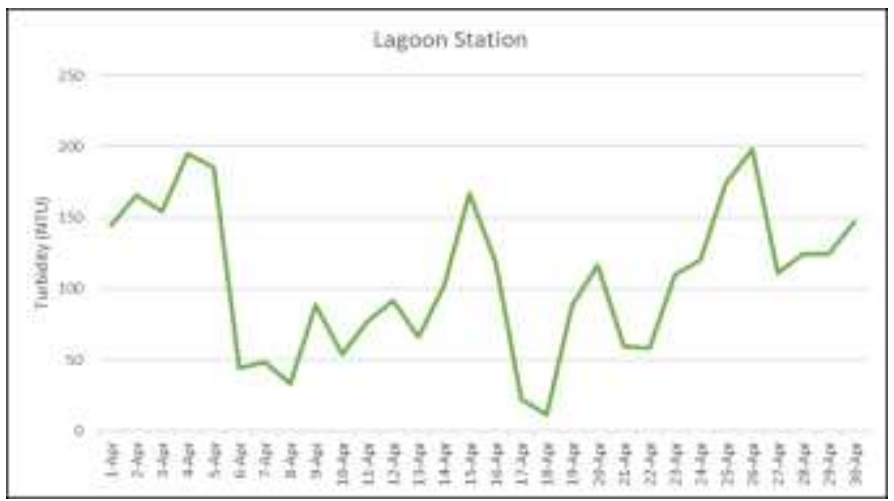

Fig. 6: Shows comparable data of Turbidity of the exact three locations of the creek in the year $2005 \& 2020$.

The input of freshwater dilutes the salinity of the lagoon water. During the COVID-19 Pandemic lockdown from 6th to 23rd April 2020, the results show significant positive increase in 
salinity. This might be due to the lower amount of effluent discharge due to restricted industry operating hours. The Dissolved Oxygen was in the range of $4.6-14.06 \mathrm{mg} / \mathrm{L}$. The mean DO level of the lagoon was $10.81 \mathrm{mg} / \mathrm{L}$. The salinity level of the Dubai creek lagoon is comparatively higher than the creek water (Al Zahed, 2008; Al Tunaiji, 2016) and this statement has been supported by various studies done before. This is because of the presence of photosynthetic activity by algae and the release of oxygen in the water in large amount. Thus, results indicate the lagoon is eutrophic due to discharge of nutrients (Al Zahed,2008). Moreover, the effluent release from STP, Al Awir industrial area and pumped groundwater causes and enhances algal growth and photosynthetic activity (Al Zahed, 2008). During the COVID-19 Pandemic lockdown from 6th to 23rd April 2020, the results show a significant positive drop in DO at the lagoon station.

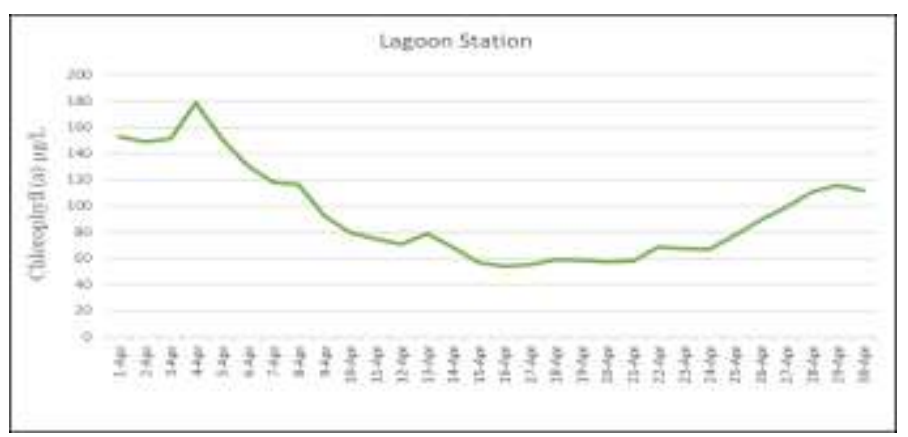

Fig. 7: Shows Pre-Lockdown, Lockdown (6-23rd April) \& Post Lockdown data of Chlorophyll (a) level of Dubai Creek.

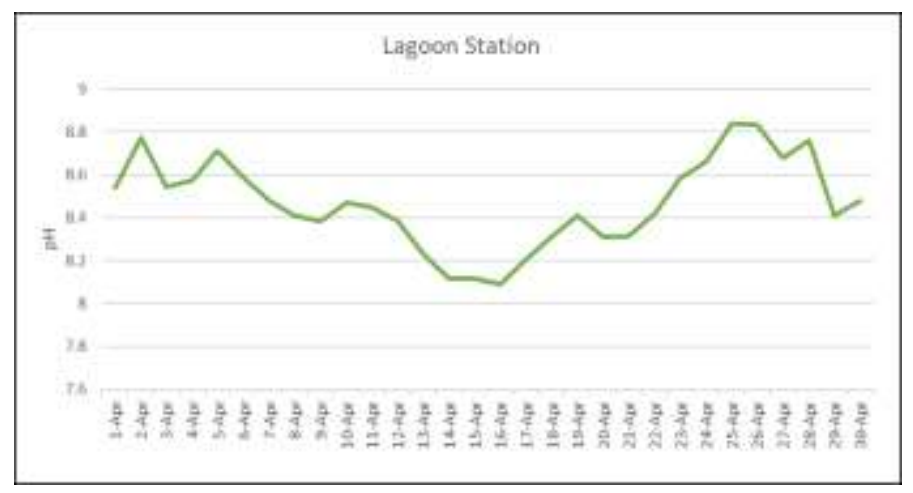

Fig. 8: Shows Pre-Lockdown, Lockdown (6-23rd April) \& Post Lockdown data of pH level of Dubai Creek lagoon.

The Turbidity was in the rage of 11.23- 197.99 NTU. The mean turbidity level of the lagoon was 106.78 NTU. The Turbidity level of the Dubai creek lagoon is comparatively higher than the creek water (Al Zahed, 2008; Al Tunaiji, 2016) and this statement has been supported by various studies done before. This is because of higher amount of presence of suspended particles like Phytoplanktons, sand particles, nutrients, algal boom etc. During the COVID-19 Pandemic lockdown from 6th to 23rd April 2020, the results show a significant positive drop. There is sudden increase in turbidity on 14-16th April, this might be due to rain as there is sudden rise in algal bloom after the rain.

The chlorophyll is in the range of $54-178.5 \mu \mathrm{g} / \mathrm{L}$ in the lagoon. The mean vale of Chlorophyll (a) in the Dubai creek lagoon was $93.84 \mu \mathrm{g} / \mathrm{L}$. The Chlorophyll (a) level of the Dubai creek lagoon is comparatively higher than the creek water ( $\mathrm{Al}$ Zahed, 2008) and this statement has been supported by various studies done before. This is due to higher algal growth and high photosynthetic activity in the lagoon. Higher the algal bloom, higher will be the chlorophyll content in the water. This also indicates eutrophic conditions in the creek lagoon. During the COVID-19 Pandemic lockdown from 6th to 23rd April 2020, the results show a significant drop in the level of chlorophyll. This shows lockdown did have a positive impact on the lagoon water quality.

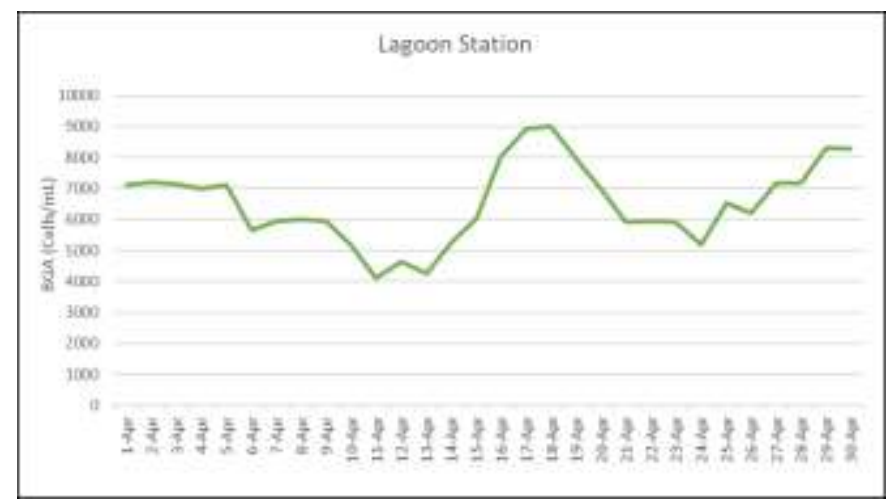

Fig. 9: Shows Pre-Lockdown, Lockdown (6-23rd April) \& Post Lockdown data of BGA level of Dubai Creek lagoon.

The $\mathrm{pH}$ is in the range of 8.09-8.84. The mean $\mathrm{pH}$ of the lagoon was 8.47. The $\mathrm{pH}$ level of the Dubai creek lagoon was comparatively higher than the creek water (Al Zahed, 2008) and this statement has been supported by various studies done before. This indicates that the lagoon is highly alkaline. This might be due to the presence of algae in the water. During the process of photosynthesis, the $\mathrm{CO}_{2}$ of the water is consumed, and oxygen is released, this increases the $\mathrm{pH}$ of the water making it very alkaline. There is a weak positive relation between $\mathrm{pH}$ and Chlorophyll (a). As the photosynthesis activity decreases, the chlorophyll (a) content in the water decreases and so the $\mathrm{pH}$ level of the water decreases. Moreover, as the dissolved oxygen will increase, the $\mathrm{pH}$ of the water will also increase (Al Zahed, 2008). During the COVID-19 Pandemic lockdown from 6th to 23rd April 2020, the results show a slight positive drop in the $\mathrm{pH}$ of the lagoon water.

The BGA in the lagoon was in the range of 4114.5-9013 cells $/ \mathrm{mL}$. The mean BGA level in the lagoon was 6539.6 cells $/ \mathrm{mL}$. The BGA level of the Dubai creek lagoon was 
comparatively higher than the creek water (Al Zahed, 2008) and this statement has been supported by various studies done before. BGA is a major threat to water quality in Dubai creek. The nutrient-rich water and warm temperature support the growth of cyanobacteria. These produce toxins deplete oxygen and choke water bodies and aquatic animals in the water. During the COVID-19 Pandemic lockdown from 6th to 23rd April 2020, there is a clear positive drop in the BGA level in the lagoon. However, sudden increase in BGA level after 14th April might be due to an influx of nutrients due to rain.

\section{Conclusion}

The results obtained from continuous real-time monitoring are not within the recommended range but showed little improvement during the COVID-19 lockdown. There was significant improvement noted in the DO, Turbidity, Salinity, Chlorophyll (a), pH and BGA during the Lockdown. However, no significant effect was observed in the water temperature of the Lagoon. The overall quality of the water improved because of less industrial operating hours during the lockdown. The opening of the canal might have minor positive effects on lagoon water due to better circulation. Tertiary treatment of STP water before discharging might help improve the water quality along with dredging of the lagoon area (Al Zahed, 2008).

\section{Acknowledgement}

Authors would like to thank Dr. Hridya VK , Tridel Technologies, FZC, QD01, Dafza Industrial park, Al Qusais, Dubai, UAE for providing necessary facilities to complete this research work. Authors would also like to express deep gratitude to Faculty members of Amity University, Noida, for valuable guidance throughout the study.

\section{References}

Al Tunaiji, Naama (2016). Water Quality Analysis In Dubai Creek, UAE: With The Focus On Heavy Metals And Nutrients. 10.13140/RG.2.2.29863.55206.

Al Zahed, K.A. (2008). Coastal zone management in Dubai with reference to ecological characterization along Dubai Creek.

A.P. Yunus, Y. Masago and Y. Hijioka, COVID-19 and surface water quality: Improved lake water quality during the lockdown, Science of the Total Environment (2018), https://doi.org/10.1016/j.scitotenv.2020.139012.

Clifford, C. (2020) The water in Venice, Italy's canals is running clear amid the COVID-19 lockdown - take a look [WWW Document]. URL https://www.cnbc.com/2020/03/18/photoswater-in-venice-italys-canals-clear-amidcovid-19lockdown.html .

Chauhan, A., Goyal, P., Verma, A and Jindal, T (2015) In -Vitro Antibiotic Resistance and Heavy Metal Tolerance Patterns of
Gram-Positive and Gram-Negative Bacteria Isolated From Effluent Treated Water of Delhi, India. Journal of Current Pharma Research 5 (2),1449-1458.

Chauhan, A., Goyal, P., Verma, A and Jindal, T (2015) Microbiological evaluation of drinking water sold by roadside vendors of Delhi, India. Appl Water Sci, DOI 10.1007/s13201-015-0315-X.

Hassan Deshgooni, Mohammad Abdul Rahman, "Modeling and Assessment of Environmental Capacity, Dubai Coastal Region, United Arab Emirates" (2002). Theses. 70. https://scholarworks.uaeu.ac.ae/all_theses/70.

Freije, A. (2015). Heavy Metal, Trace Element and Petroleum Hydrocarbon Pollution in the Arabian Gulf: Review. Journal of the Association of Arab Universities for Basic and Applied Sciences.

Mani, K.S., (2020) The Lockdown Cleaned the Ganga More Than 'Namami Gange' Ever Did [WWW Document]. URL https://science.thewire.in/environment/ganga-riverlockdowncleaner-namami-gange-sewage-treatment-ecological-flow/.

Mitra, Abhijit \& Mitra, Ankita. (2020). COVID-19 Lockdown phase: A boon for the River Ganga water quality along the city of Kolkata.

Mohan, M., Chandran, M.S., Jayasooryan, K., Ramasamy, E. (2014) Mercury in the sediments of Vembanad Lake, western coast of India. Environmental monitoring and assessment 186.

Murad, A. (2010). An Overview of Conventional and Nonconventional Water Resources in Arid Region: Assessment and Constrains of the United Arab Emirates (UAE). Journal of Water Resource and Protection

How to cite this article:

Rajshree, Chauhan, A., Ranjan A., Jindal T. (2020) Impact of COVID-19 lockdown on water quality of Dubai creek lagoon Science Archives, Vol. 1 (1), 1-6.

DOI: http://dx.doi.org/10.47587/SA.2020.1101

This work is licensed under a Creative Commons

Attribution 4.0 International License.

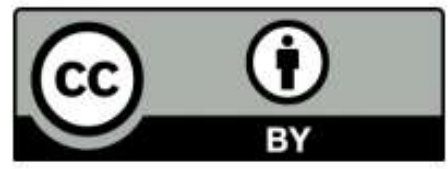

